\title{
Community treatment: a civil solution?
}

\author{
Harry Kennedy
}

In this issue of the Bulletin, Pinfold et al (1999) report what appears to be the very gradual acceptance of the supervised discharge provisions which were introduced by the last government despite widespread criticism by psychiatrists and others. Perhaps most disturbing is their identification of a belief that the provisions allow community treatment orders by the back door, since patients perceive supervised discharge as a threat that they will be readmitted to hospital if they do not accept medication 'voluntarily'. Also in this issue, Sugarman (1999) proposes a series of ways in which the courts might extend the advantages of conditional discharges made under the criminal provisions of the Mental Health Act 1983. Yet conditional discharge also has at its heart a 'back-door' route to compulsory treatment in the community. Patients have no right to seek formal second opinions regarding the treatments prescribed, which are presumed to be taken voluntarily, though patients usually realise they will not be granted conditional discharge unless they accept prescribed medication, and will be recalled to hospital if they default.

People with schizophrenia who commit suicide, or who harm others, are almost always regarded as diminished in their responsibility. All too often however, there is no legal provision that allows mental health services to intervene in good time to prevent relapse; even when relapse is predictable. There is, therefore, an unacceptable gap between the humane recognition that treatment is more appropriate than punishment where responsibility is diminished, and the lack of power to prevent harm that is supposed to be foreseeable. Clinicians who find themselves caught in this gap between freedom and responsibility, are perceived by the public as culpable, even though impotent. This resembles another gap in mental health law in the UK concerning incapacitated patients who cannot consent, but do not protest (Eastman \& Peay, 1998), and the ideal solution may be common to both.

Department of Health policy guidelines concerning the Care Programme Approach and the Supervision Register emphasise that the responsible medical officer should not discharge patients until it is safe to do so. Yet the diagnostic test of Section 1 of the Mental Health
Act 1983 often leads to discharge, either by Mental Health Review Tribunals or by the responsible medical officer, in the knowledge that a Mental Health Review Tribunal would discharge, long before the responsible medical officer can be confident of safety. Remission, or the appearance of remission, is no guarantee of adherence to treatment and cooperation in the community. Against advice and in breach of promises, patients often stop medication, move back in with contentious relatives or return to substance misuse and relapse with predictable consequences. How important is this impotent foresight? How can this foresight be used without an unwarranted infringement of rights?

Until now, it has been widely assumed that Article 5 of the European Convention on Human Rights (Brownlie, 1983) forbids the use of community treatment orders. This is by no means a clear interpretation of Article 5, which prescribes:

"Everyone has the right to liberty and security of person. No one shall be deprived of his liberty save in the following cases and in accordance with a procedure prescribed by law . .

(b) The lawful arrest or detention of a person for noncompliance with the lawful order of a court or in order to secure the fulfilment of any obligation prescribed by law. . .

(e) The lawful detention of persons for the prevention of the spreading of infectious diseases, of persons of unsound mind, alcoholics or drug addicts, or vagrants."

In common law jurisdictions, it is generally held that the 'penalty' in the criminal courts should be proportionate to the crime. This makes indefinite sentences difficult to justify. Indefinite powers to treat can only be imposed where there is a conviction for a serious offence and usually evidence of previous offences. Article 5, however, does not in any obvious way appear to prevent the use of indefinite provisions (subject to rights of appeal) by civil courts on the grounds of mental incapacity.

The Law Commission's report on Mental Incapacity (Law Commission, 1995) recommends the use of functional incapacity, the inability to make a specific decision, as the 
criterion for when the courts should step in to take over the responsibility for making decisions on behalf of the incapacitated person. Functional incapacity is a narrower concept than incompetence to give consent, which requires the capacity to understand relevant information and make rational decisions and choices. The principle of functional incapacity, once recognised, is readily transferable to those with severe and enduring mental illnesses.

Many patients with 'functional psychoses' have an impaired capacity or complete incapacity for rational understanding regarding the nature and consequences of their illness and the relative merits and disadvantages of treatment. Delusions, or the presumed mental incapacity which causes delusions, can prevent patients from believing advice regarding treatment. This lack of capacity for insight can persist even when positive symptoms (delusions and hallucinations) are not floridly in evidence.

There is research evidence that good compliance with depot neuroleptics reduces relapses of schizophrenia (Shepherd \& Watt, 1977; Leff \& Vaughan, 1981); that fewer relapses are associated with less long-term disability (though the evidence for this requires further research); and that acute episodes including relapses, are associated with harm to others (Steadman et al 1998). The chain of causation (defaulting medication leads to relapse, to deterioration and to harm) may not be complete but is now probable. A reasonable and prudent clinician would usually advise a patient with severe and enduring mental illness such as schizophrenia to avoid relapse by staying on medication.

Should a court be able to impose treatment based on evidence of functional incapacity, without evidence of delusions, hallucinations or incapacity in other areas of daily function? The diagnostic test under Section 1 of the Mental Health Act fails to be of use if it relies only on positive symptoms (delusions and hallucinations). Clinical evidence of negative symptoms should suffice, since it supports a general incapacity. Evidence of lack of capacity for insight with adverse effects for the patient or others should also be sufficient. A history of repeatedly discontinuing medication and repeatedly relapsing, with adverse consequences for the patient or others should be sufficient to establish this. Recent research on insight into schizophrenia illustrates growing recognition of how important insight is in determining the course and outcome of chronic severe mental illness (McEvoy, 1997; David, 1997).

The solution must be a new power for the civil courts, probably at county court level. This would enable the civil courts to oblige patients to comply with community care and treatment plans where it can be shown, on the balance of probability, that the patient lacks the functional capacity to make a safe and responsible decision about continued treatment. Patients should retain a right of appeal on the grounds of demonstrable evidence of change and the detention should be renewable by the same courts.

The freedom of treating clinicians to exchange full information about patients, both the patients' full history and their current mental health problems, should be strengthened against the likely objections of patients and their legal representatives to disclosure of their past history to their current psychiatrist. Criminal record information should similarly be made formally available. Power to require hair analysis to test for compliance with medication and the misuse of street drugs should also be specifically included since those with severe mental illness are at greater vulnerability to addictions than others and the risk of harm is particularly high in those with co-morbid substance misuse (Steadman et al, 1998).

\section{References}

BROWNLE, I. (1983) Basic Documents in International Law (3rd edition). Oxford: Clarendon.

DAVID, A. S. (1997) The clinical importance of insight. In Insight and Psychosis (eds X. F. Amador \& A. S. David). pp. 332-351. Oxford: Oxford University Press.

EASTMAN, N. \& PEAY, J. (1998) Bournewood: an indefensible gap in mental health law. British Medical Journal, 317. 94-95.

LAW Commssion (1995) Mental Incapacity: item 9 of the fourth programme of law reform. In Mentally Incapactated Adults. Law Commission No. 231 . London: HMSO.

LEFF, J. \& VAUGHAN, C. (1981) The role of maintenance therapy and relattve expressed emotion in relapse of schizophrenia: a two-year follow up. British Journal of Psychiatry, 139, 102-104.

MCEvoy, J. P. (1997) The relationship between insight in psychosis and compliance with medications. In Insight and Psychosis (eds X. F. Amador \& A. S. David). pp. 289-306. Oxford: Oxford University Press.

PINFOLD, V., BINDMAN, J., FRIEDLI, K., et al (1999) Supervised discharge orders in England: compulsory care in the community. Psychiatric Bulletin, 23. 199-203.

SHEPHERD, M. \& WATT, D. C. (1977) Long-term treatment with neuroleptics in psychiatry. Current Developments in Psychopharmacology, 4, 217-247.

Steadman, H. J., Mulvey, E. P., Monahan, J., et al (1998) Violence by people discharged from acute psychiatric in-patient facilities and by others in the same neighbourhoods. Archives of General Psychiatry. 65. $393-401$.

SUGARMAN. P. (1999) New community mental health law: the conditional discharge model. Psychiatric Bulletin, 23. 195-198.

Harry G. Kennedy, Consultant Forensic Psychiatrist, Camlet Lodge Secure Unit, Chase Farm Hospital, Enfield EN2 8JL and Honorary Senior Lecturer, University College London and Royal Free Hospital Medical School 